China Perspectives

45 | january-february 2003

Varia

\title{
The Five Yuan
}

Shi Shuqing

\section{(2) OpenEdition}

Journals

Édition électronique

URL : http://journals.openedition.org/chinaperspectives/237

DOI : 10.4000/chinaperspectives.237

ISSN : 1996-4617

\section{Éditeur}

Centre d'étude français sur la Chine contemporaine

\section{Édition imprimée}

Date de publication : 1 février 2003

ISSN : 2070-3449

\section{Référence électronique}

Shi Shuqing, "The Five Yuan », China Perspectives [En ligne], 45 | january-february 2003, mis en ligne le 23 novembre 2006, consulté le 28 octobre 2019. URL : http://journals.openedition.org/ chinaperspectives/237; DOI : 10.4000/chinaperspectives.237

Ce document a été généré automatiquement le 28 octobre 2019

(c) All rights reserved 


\section{The Five Yuan}

\section{Shi Shuqing}

\section{NOTE DE L'ÉDITEUR}

Translated from the Chinese original by Caroline Mason

1 The hillside slopes very steeply here, and the earth is so hard and dry that it looks as if it is covered with shards of tile. You can't grow anything in a place like that, which is probably why it came to be used as the village graveyard.

2 Grave-mounds dot the steep slope here and there, but considering that for many years now every single person who has died in the village has been buried here, there aren't many mounds to be seen. This is because a number of the oldest ones have gradually been worn away by the wind and rain. Some of them have disappeared altogether, and all that remains of others is a small bump, hardly perceptible unless you step on it or feel it with your hand-a slight swelling on the surface the only sign that there was probably once an old grave there.

3 But there are actually masses of bodies buried beneath this hillside, and even the villagers can't say for sure whether there is someone buried in this or that small patch of ground. When there is a death in the village, the gravediggers sometimes walk up and down like prospectors, hunting for a vacant plot. They'll choose a level area which appears to be unoccupied, and start digging, very gingerly, but then they'll unearth human remains, sometimes new ones, sometimes old, so they hastily refill the hole and move elsewhere, to start digging again. This happens almost every time, and it's very discouraging for the diggers. You see a little pile of freshly-turned earth in the graveyard, slowly changing colour, and it's easy to tell, from the colour of the soil, how many hours of digging it represents.

4 Just at this moment, the gravediggers seem to have grown weary of their work. They have put down their picks and shovels and are squatting among the graves to eat their $m o m o^{1}$ and have a drink of water. Their hands are covered with dirt, but since there is no way to wash them, they just hold them up to their mouths and blow on them hard a 
few times, though that doesn't seem to dislodge anything at all. Then they break open their momo and begin to eat.

Their faces are the same colour as the soil which they throw up when digging graves: they are the regular gravediggers for the village, and the family of the deceased always pays them a mietie ${ }^{2}$, possibly as much as 15 yuan, or even 20, but at the very least seven, and in any case an amount not to be sneezed at. Every so often, as if in obedience to some law, they shoulder their picks and shovels and come out here to dig a grave. But today's grave is clearly not an easy one to dig. They got here before the sun was very high in the sky, yet all they've managed to do by the time they stop for a break is to make a small pile of soil, and you couldn't honestly call what they've dug a hole! The lumps of earth they have dug up are as hard as logs split with an axe. The walls and bottom of the hole are covered with soil which their picks have dislodged, and when it's shovelled up, bit by bit, the marks made by their picks can be seen very close together, resembling a forest of strange, raised hands. The livid colour of many of these marks seems to express hostility and hatred.

6 The grave is getting harder and harder to dig.

7 There isn't a single blade of grass more than five inches high in the whole graveyard. It's not that there isn't any grass-there's plenty of it-but it's of a kind which looks as if it has been trampled by the feet of thousands as soon as it emerged from the earth: cramped and despairing, it resembles dried cow-dung lying on the ground. Even when grown it looks more like a root than a plant. People here call it " grass-tail", and there couldn't be a more fitting name for it. You never see this grass shake, even in the strongest wind. There isn't actually anything here for the wind to shake.

8 Sitting beside their little mound of soil, the strapping gravediggers are not living up to their reputation for hard work. Like soldiers after a defeat, they're sitting around eating, drinking, telling jokes. A biting wind blows through the graveyard in gusts which set their ears vibrating.

"Hajij ${ }^{3}$, when it's your turn, try not to die in winter! The earth in winter is harder than stone, and even if we were paid extra to dig deeper, I'd never manage it!"

10 "If the Creator decides on winter, then winter it will be, and no one can do anything about it", says the one they call Hajji, philosophically. He has a brown beard which juts out stiffly from his face. He sticks out his tongue and gently licks the spot on his hand between the thumb and the index finger, the one known as the "tiger's mouth". It's painful, like a burn. The tip of his tongue licks the dirt off the spot, and that makes it feel better, although the blood seems ready to ooze out from beneath the maze of lines on his hand. He goes on: "But I think that dying in winter has something to be said for it-the grain is safely in, and the earth is resting. You just stay at home, with nothing else to do but eat! But if you die in the spring, who will do your sowing? And if you die in the summer, or the autumn, who will harvest all the stuff you took so much trouble to sow?" He presses hard on the "tiger's mouth" with the thumb of his other hand, and massages it back and forth.

11 As he speaks these words of wisdom, one of the other gravediggers has noticed the position of the sun, and jumps hastily to his feet. "Quick, you lot, back to work! Look at the sun! If they bring the body now, and we haven't even finished digging the grave, what on earth will we do!" 

you'd have to check their identity cards to find this out. The Li Xiuhua who has died hardly ever used that name in all her sixty-eight years on this earth, so telling the villagers that Li Xiuhua had died would have had them puzzled: they could tell from the name that the deceased was a woman, but they'd have had no idea which one. Even if you'd called out to the late Li Xiuhua herself, using her name, it would have taken a while to register with her. But if you'd said "Ma Liangdong's mother", or "Ma Wenshan's wife", everyone would have known at once who you were talking about-oh yes, the woman who has died, and is awaiting burial.

16 A group of women and girls, relatives of the dead woman, are weeping loudly around the bed. On the sideboard, the clock ticks steadily, without faltering, showing a dignity and sense of mystery befitting the occasion, as if the stillness and tranquillity emanating from the dead woman have somehow made its rhythm stronger and more confident.

17 Now and then people come in, lift a corner of the white cloth to look at the face of the dead woman, and go silently out again. Taking such a look is an extremely important matter, for the face of a dead person is the last mirror that person leaves to the rest of the world and the key to the sort of life they have led. If the face of the deceased is lean and yellow as an autumn leaf, people will think he or she lived a pure life and will rest in peace; if the face is round and black, as if charred, inevitably tongues will wag.

18 There are people standing around in the courtyard, too, in various attitudes. No one seems to know what to do.

19 One of the dead woman's sons works in the county town, which explains why there are some city folk among the mourners. They stand apart from the villagers, the two groups as distinct as plots of land planted with totally different crops.

The younger of the dead woman's two daughters got engaged recently, but isn't married yet. She has cried herself hoarse, and is lying face-down on the raised platform in the yard, weeping, her thick black plaits hanging down and touching the ground. A cock walks across the yard to investigate what there is to eat, pecks around fruitlessly and goes away again, grumbling to himself. A woman crosses over to the girl and lifts her heavy plaits onto the platform. She pats the girl's head and moves away, wiping her eyes. 
21 In another part of the courtyard, a little further off, a few women are standing mournfully round a bowl full of wet clothes. The dead woman must have put them there to soak, they're saying, but didn't have time to wash them before she died.

The women talk quietly among themselves. When a woman dies, it gives the other women in the village a rare chance to get together for a chat. These discussions can clarify many matters and make the women aware of things they were totally in the dark about before. They are very displeased with the behaviour of Ma Wenshan, who is squatting beside a ditch with another man and having a whispered conversation, punctuated with laughter. How dare he laugh like that! It's disgusting! The women would like to ask him, "Have you forgotten that your wife is still lying on the bed inside the house just over there, and she hasn't even been buried yet? Don't you remember all she did for you, how she kept the kang warm for you all those years, and served up all those meals?"

The sun ambles across the sky, at such a leisurely pace that it makes people drowsy. The trees stand miserably in the yard, as if they have been abandoned. They probably look so tall and defenceless because it's winter, and there are so few leaves left on the branches. They all convey the impression of being very solitary, though there are quite a lot of them, and they are not far apart from each other.

The sun has reached its zenith, when it's too risky to look at it. It seems to hesitate, unsure whether to go on or back, as if wondering "Now where do I go?"

A child, dressed in mourning, comes running up to announce, "The in-laws are here, the in-laws are here!" He means the dead woman's family, the one she left when she married.

Almost at once they hear the sound of chanting, coming from a long distance away on the road outside, and the atmosphere in the courtyard suddenly becomes more strained. A few men dressed in deep mourning, together with the elders of the village and Ma Wenshan, move towards the gate with the ahong ${ }^{4}$ of the district in their midst. White caps bob this way and that, like flowers in a strong wind. All the men here are Hui, but customs differ from one district to the next, and although in many places the mourning-dress of the Hui is very simple, for today's funeral the four strapping sons of the dead woman are in deep mourning, and swathed in white from head to foot. The crowd are awed by this, because it makes them look as if they are on their way to Paradise-or else to the execution-ground.

The men swiftly make their way a short distance beyond the gate, to meet the dead woman's family, who arrive covered with dust from their long journey.

Today, the dead woman's family are the guests of honour, and must be treated with the utmost consideration. If they feel unhappy about something today they even have the right to show their anger by tipping the table over, and many tables have been overturned on such days in the past. The two groups of players in this drama stand motionless, a few yards apart, in front of the gate, near the place where the grain is ground. The villagers fold their arms and wait respectfully for the newcomers to finish their chanting.

In this highly-charged atmosphere, the sons of the dead woman cannot hold back their tears: it's the first time that all the members of their mother's family, old and young alike, have turned out in such strength and come to her home together like this, and some of them have never come before at all. It was not given to their mother to see 
such a splendid sight while she was alive-that's how it is with some things, you never get the chance to see them during your life-time.

Now that everyone has gone out, the room where the dead woman lies is empty. The last of the sobbing mourners round the bed have been persuaded outside to watch what is going on, and she is left alone under the thin white cloth, as quiet and tranquil as a jar of water.

31 The main room of the house is small, and packed with people, like an old wooden chest stuffed full of odds and ends. It is permeated by a sense of age-old simplicity and grief, but also of human warmth, in which people are very glad to immerse themselves. The family of the deceased kneel on the kang with suitable solemnity, and their hosts kneel on the floor.

The time has come for the two sides to confess their failings honestly to each other.

First, it is the turn of the Ma family to give an account of their faults. Ma Wenshan's brother, Ma Wenqing, takes on this task.

With an appropriately sad expression on his thin face, he starts off: "Kinsmen, we are so ashamed that we don't know what to say. You freely presented our family with one of your own family members, and for many, many years she looked after our old folk and brought up our children and, to be honest, it was very hard work indeed. What grieves us is that my sister-in-law never enjoyed any happiness in our family, but had more than her fair share of hardship. You all know what times were like when she first came to us, and I will say no more about those years. But recently things have got a little easier, and some of her children have not been doing too badly, though no one could call them wealthy, exactly. We really meant to take care of her properly in her old age, and there was no way we could have known she would die early and leave us so suddenly. The children never had the chance to look after her as they would have wished, and neither did we, and that is how we have done her wrong. If she had had a few days of illness, and her children could have given her some medicine, or propped her up on pillows, they would feel less remorse, and we too would feel a little easier in our minds. Though of course, if we look at it differently, the good thing is that she didn't have to suffer even a headache, she didn't have a fever, and her death was an easy one, no doubt because she was such a good woman. I've had the chance to say these few words to you, but when all is said and done, we feel so ashamed that we don't know what to say. Now our sister-in-law has come to the end of her allotted span and passed on, and it is your turn to say what you have to say. Our sense of shame is so great that we'll keep our mouths shut even if you curse us and send the tables flying."

Though he has used "Say what you have to say" in a neutral way here, what he means is, "We need to settle accounts."

It is the dead woman's brother, an old ahong of imposing appearance, who speaks for the other side.

He says, "Our sister came over here to be married when she was fifteen, and I remember very clearly how she left our home in a cart, and took a day and a night to get here. I'm happy that ever since then, right up to today, our two families have got along well together. That is what matters most. There's no need to tell us that she never had any happiness, no need to tell us she had a difficult time. Didn't we all go through that time? But she never had to cope with a major disaster, she was able to live in peace, and to return to her original purity at her death: if that isn't 'happiness', what 
is? Though her sons, my nephews, are still not very well off, they did everything that they could for her, and have demonstrated their filial piety perfectly well-it's just that you children are now motherless, and will be yat' $m^{5}$ from today on."

Sobs choke the old ahong, and the dead woman's sons, kneeling on the floor, are so moved they can no longer hold back their grief, and keep having to wipe away tears with their big hands.

"Let me continue", says the old man. "She was part of your family for a very long time, and there must have been some squabbles and difficult patches during that period. If our dear sister did wrong to anyone at such times, we beg you to forgive her, now that she is no more."

And with that, the confessions are over, everyone is satisfied that duty has been done, and the continuation of harmonious relations is assured.

Next comes the reading of thirty sections of the Koran, and the start of the $d u^{\prime} \hat{a}^{6}$ invocations, using the beautiful and mysterious black and white stones.

When that ritual has been completed, the mietie is distributed, and the Ma family are very generous to the relatives of the deceased woman, giving 50 yuan to the ahong and 10 yuan to everyone else, young and old, men and women, even babes-in-arms. This pleases the dead woman's family greatly, because they are aware they are being treated with respect, and their pleasure is reflected in their faces.

The distribution of the mietie is followed by the thanksgiving du'â.

As everyone stands for the $d u$ 'â, the palms of their hands upwards, as if they were holding books and reading from them, the sound of a woman weeping is suddenly heard in the courtyard. People are startled, because no one has cried as loudly as this for a while now.

When Liu Fengcheng's wife heard about Li Xiuhua's death her heart sank, because she immediately recalled the five yuan that the dead woman had borrowed from her. "Now that she has died, and so unexpectedly, what can I do about the money?" she wondered. She stayed indoors, but was too upset to keep still for long. Her husband had probably gone to the dead woman's house, and her own house seemed so empty. They haven't got any children, so they have never had the house done up, and it looks very shabby. But all the bowls and plates in the place have been washed and scoured so often over time that they almost seem to be alive.

She's so far from being so well off that she doesn't mind about the five yuan-but in fact, she's really distressed about it. She'd like to be able to forget about it, to think of something else, but it was impossible-it was the only thing she could think about. If only it could have been sorted out before, she thought. And then she felt ashamed of herself. "Li Xiuhua is dead, how can you be so mean about this? You don't honestly think she would die simply in order to avoid paying you back your five yuan, do you?"

But she still felt unhappy, even rather resentful, and unsure what to do. First she blamed the dead woman, then she blamed herself, until she was in a total muddle. If only she'd asked for it back before! If she had, then she could just go along to the funeral and things wouldn't ever have become so complicated and messy. But she never did ask for it back.

Let's just put the relationship between the two women to one side and look at the facts. One, the loan happened fairly recently; two, although of course five yuan is not an 
inconsiderable sum to Liu Fengcheng's wife, it isn't a huge amount. Besides, and more importantly, Li Xiuhua must definitely have been short of money for a time, because she would have paid her back if she'd had any, without needing to be reminded, she knows that. It's just that she never imagined such a good woman would suddenly up and die like this.

Deep down, she began to regret having lent her the money.

It had happened only a couple of weeks ago, when the two of them went to the local market, and of course neither woman knew how much money the other had on her. Li Xiuhua bought a kilo of salt and a packet of washing-powder, and then she bought two packets of dye and a thimble from a peddler. Liu Fengcheng's wife bought only a pair of shoes for herself, and two ounces of tea for her husband. She has been regretting having taken out her money when she bought the things, because it must have looked as if she was showing off dreadfully. When she was buying the shoes she'd opened up the handkerchief in which she kept her money, without a thought of trying to hide it, and the same thing happened again when she was buying the tea. Hadn't she in a way compelled the other woman to see how much she had? And yes, it was after she'd bought the shoes, and the tea had been weighed and wrapped, and they'd decided to go home that, all of a sudden, Li Xiuhua confessed rather sheepishly that she'd liked those shoes too, but she didn't have enough money to buy them. They cost six yuan, and she only had one yuan left.

Her heart fell when she heard this, and she was in such a quandary she didn't know what to say.

"Will you be buying anything else?" Li Xiuhua asked her, and without waiting for a reply she went on rather miserably, "Because if not, I wonder if you could you lend me some money, and I'll pay you back as soon as I have any." Though it was Liu Fengcheng's wife who had bought the shoes a little earlier, both women had tried them on. It would have been churlish to refuse her the money, and she obviously couldn't now say she had other things to buy. Though she felt very unhappy about it, she knew she didn't have any choice but to lend the money. "All those sons, and you're still short of money!" she said.

Li Xiuhua flushed red, as if someone had touched a raw nerve. She turned her head away and looked dully at a concrete post nearby.

"Let's go home," she said abruptly, and started off in the direction of the village. Now it was the turn of Liu Fengcheng's wife to feel flustered. She grabbed the other woman's sleeve and protested, "I never said I wouldn't lend it to you-go on, buy them, see if you can't get yourself some even nicer ones than mine!"

Li Xiuhua responded, "No, I don't feel like buying them after all." This made Liu Fengcheng's wife feel even worse. She felt that she had absolutely no alternative but to lend her the five yuan, and even if Li Xiuhua had now decided she didn't want to borrow the money, she would make her take it.

58 "Oh dear, are you angry with me? Well, I don't care", she said, and smiled. She grabbed Li Xiuhua's arm so hard that it hurt, and dragged her back with her.

When they emerged from buying the shoes, Li Xiuhua was much more cheerful, and though by then the subject of their conversation had long moved on she said, "My sons have lives of their own to live, you know, but don't worry-I'll pay you back as soon as I get any money!" 

are people standing there and she feels they are all watching her, as if she has done something unspeakable. She walks on, head down, and without looking at them goes into the room where the dead woman lies. wall of the courtyard and stops beside it, thinking about the face she has just seen. It is so pale, so peaceful, unmarked by worry or anything out of the ordinary. This surprises her, because it isn't what she expected. 
74 As she stands next to the wall she is prey to many different thoughts, and they are so unbearable that she breaks into loud sobs. Everyone looks at her now, of course, but it's no good, she can't stop, and with her head turned to one side she leans with her hands against the wall and weeps, facing the tall, leafless trees.

The blinds are now raised in the small, crowded main room and people are leaving the pitch darkness there and surging out into the yard, casting disconcerted glances at the weeping woman as they emerge.

She continues to weep, all alone, aware only of the few solitary trees in the yard, which are so tall it makes her giddy to look at them.

After some time, she feels a sharp tap on the shoulder-there is someone behind her, but she turns away and goes on crying. There are more taps on her shoulder, and a cross-looking man tells her to stop crying, because they're now bathing the body.

This is the final wash the dead person will have. There must be no weeping while the ritual is being performed, because it might frighten the dead person and make their joints contract and become painful.

She tries as hard as she can to suppress her sobs, but her mouth is trembling so much that it's impossible to stop at once, and her throat heaves like a frog's when it basks in the sun.

80 Just then the lad whose job it has been to keep people informed about what is happening dashes into the yard and announces that the grave isn't ready yet. Many of the people there cast anxious glances at the sun. If the grave isn't ready yet, when will it be?

The gravediggers have seen the funeral procession in the distance, getting closer and closer, like a storm-cloud. They begin to panic.

"They're coming! They're coming!"

They all talk at once. Each of them seems to have gained some extra energy from somewhere. And they truly haven't been slacking all this time. What good would that do? It's their job, after all, it's what they're here for. Come on then, shut up and keep digging!

They are actually more concerned than anyone else, because no one knows better than they do what it means for a dead person to return to the earth-for that person it is like finding some precious treasure they had lost. They see the sun sinking little by little into the west and wish they had a pole or hook of some sort to hold it back with. One thing is certain-they haven't finished digging the grave, and the dead woman is almost here. They knew she would be coming, of course, but had no idea it would be so soon!

The earth is getting harder the deeper they dig, it's never been this hard before. Down they go, and keep finding rocks. They are digging as hard as they can, and breaking up the rocks as they go. The grave is so hard to dig that even their picks are feeling the strain. They hate these rocks-it's been almost as if they were hiding there on purpose, just to give them a tough time - but by now they feel quite glad to have piles of the vile things lying around as proof of the difficulty they've been having.

Why haven't they dug any deeper? There's no need to ask-just look at the rocks! But in spite of the perfectly convincing reason for the delay, they still blame themselves, and 
they'll only feel happy when the job is done. Heads down they struggle on, without a glance at the crowd of people who are approaching.

What a lot of them there are! They must have come from several of the neighbourhoods close by-a neighbourhood round here being the same thing as a village. The cortege forges ahead, the wind behind it. The dead woman is raised aloft, to give her a better look than she has ever had before, and from a higher viewpoint, at the place where she lived all these years.

Eventually the body is laid down on the hillside. It is so steep at that point that there is a real risk it could roll down the hill, so some of the people wedge it securely on one side with clods of earth which will later be put on top of the grave.

The wind is getting up, and whipping constantly at the white cloth wrapped round the body. The clothes of the crowd too are flapping noisily, and the whole graveyard is filled with the roar of the wind.

91 People are standing round the grave now, watching. The gravediggers dare not even raise their heads, they just keep toiling away, sparks flying every time their picks strike rock.

Someone asks, "How come there's all this rock?"

Someone else remarks, "It's lucky they haven't broken through." Round here, that means that with so little room left in the graveyard, they are lucky not to have found themselves digging into a pre-existing grave. The ahong calls on everyone to stand up straight, while he conducts the janaz $a^{7}$ for the deceased. The gravediggers brush the dirt off themselves, wipe the sweat from their brows and prepare to join in, but the ahong tells them to carry on digging, and they do as he says.

When the service is over, the crowd spreads out, and old and young alike kneel among the crumbling graves. Those of them who can read the prayers get out their copies of the Book and begin chanting. The pages are fluttering so wildly in the wind that even a hand spread over the Book can't hold them down.

The women and girls kneel further from the graves than the menfolk.

The wind blows off the caps of several of the men present, and they have to hurryscurry after them while others watch, their hands pressed to their heads to keep their own caps on. One man has to chase his cap right down into the ravine before he catches it.

97 Their faces grow stiff and numb as rock in the bitter wind. Some of the people from town have put on their dark glasses.

98 The service is over, the readings are finished-but still the grave is not ready. It is supposed to be deep enough for a person to stand in with his arms raised, but at the moment if a man stood up in it you'd still be able to see most of his torso.

Everyone is on their knees in the steeply sloping graveyard, the wind is blowing a gale, and nobody knows what to do next. With nothing to do, and unsure whether to sit or stand, some of them cast around for something, even a blade of grass, to pick-but there is nothing. It is hardly possible now, in the howling wind, to tell the city folk apart from the villagers. Although the graveyard is jammed with people, there isn't a sign of life on the hillside, and in the merciless wind it presents a picture of loneliness.

100 The sound of the picks as they strike the rocks is as clear and sharp as ever. It's almost as if they are fastening down the heavy curtain of wind with nails of stone. 
101 All at once the wind seems to mark out the dead woman for attention. It starts to whip insistently at her shroud, as if it's blowing across a pool of water and forcing it into a corner it can't get out of. If the cloth wasn't tied so tightly round her body it would have been blown away long ago.

One of the dead woman's sons, the one who works in the county-town, now addresses a salaam to all the people kneeling around him in the graveyard. While they are all there, he says, he wants to ask them something: since there are times in all our lives when we may be a little bit better off, and other times when money is short, he wonders if perhaps his mother ever borrowed from any of the villagers who are here at her funeral? If she did, would that person please make himself or herself known, and he will reimburse them at once, in front of his mother, so that the old lady can go peacefully to her rest. He speaks touchingly and with great sincerity, and the people kneeling there woodenly in the howling wind begin whispered consultations with one another.

Liu Fengcheng's wife is there too, on her knees among the rest of them. The wind is snapping at her scarf, trying to make it slide down the back of her head. It won't let her go, it keeps tugging at her, trying to take her away from this place. Kneeling there numbly, she doesn't know what to do. Has she really heard what she thinks she has heard?

104 "If she never borrowed anything from anyone, and everything's in order, then I'll offer you all a salaam." He turns to all four sides, one after the other, and says, "Peace be with you". This is the ritual signal that the dead woman owed nothing to anyone. Even if she had done, once he has asked this question the slate is now wiped clean.

105 The sun is on the point of setting, and the mountains are all spewing out huge, dark shadows. The pagers of some of the mourners are beeping shrilly, and in among these wild, bare mountains they sound like frightened insects. Their owners lift up the bottoms of their jackets and look at them.

106 The wind has abated a little, but it still sounds very loud, because the mourners are so silent. Seeing all these people on their knees among the scattered graves, the dead woman's relatives begin to look embarrassed and uncomfortable. The Ma family goes into a huddle with their in-laws and they discuss what should happen next. Standing for such a long time in the fierce wind has taken its toll on the old ahong, and after a heavy-hearted pause he says quietly, "Bury her."

107 The gravediggers, who have been feeling bad about the delay, sense that they have been pardoned, and lay down their tools.

108 "We won't be needing a mietie for this grave," says one of them, his face red with shame, as he scratches up some dirt from the ground and sprinkles it on the raw patches on his hands.

109 And so that's how she is buried.

110 It doesn't take long for the people at the funeral to melt away. Now there is only the hillside covered with scattered graves, and the noise of the wind as it scurries between them, beginning now to sound a little surreptitious.

111 The new grave is easy to identify. It's small and rather narrow, and it's hard to imagine that underneath that little mound of soil there is someone who lived for sixty-eight years and was the mother of six children. The grave-mound is so precariously perched 
on the steep hillside that it looks as if a gentle push might send it crashing to the bottom of the ravine.

\section{NOTES}

1. Original title Hong hua lü ye (Red flowers, green leaves).

2. Reward in cash for services, often of a religious nature.

3. Honorific title for one who has made the pilgrimage to Mecca.

4. Imam (Muslim cleric).

5. Orphans.

6. Prayer to Allah.

7. Funeral service. 